
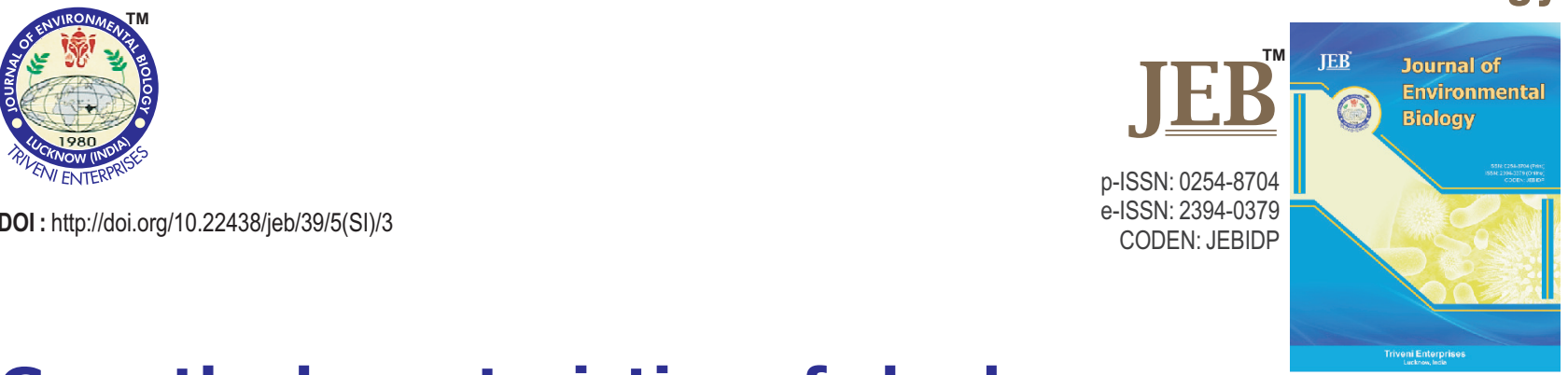

\title{
Growth characteristics of shade- acclimated marine Chlorella vulgaris under high-cell-density conditions
}

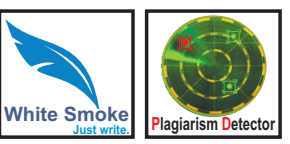

\section{Authors Info}

T. Katayama', N. Nagao ${ }^{2 *}, \mathrm{M}$. Goto $^{3}$, F. Md. Yusoff', S.

Banerjee $^{2}$, M. Sato', K. Takahashi' and K. Furuya'

${ }^{1}$ Graduate School of Agricultural and Life Sciences, The University of Tokyo, Bunkyo, Tokyo 113-8657, Japan

${ }^{2}$ Laboratory of Marine Biotechnology, Institute of Bioscience, Universiti Putra Malaysia, 43400 Serdang, Selangor Darul Ehsan, Malaysia

${ }^{3}$ Faculty of Science and Engineering, Soka University, Hachioji, Tokyo 192-8577, Japan

*Corresponding Author Email : norionagao@gmail.com

Key words

Chlorella vulgaris

High cell density

Light intensity per cell

Light-saturation index

Shade acclimation

Publication Info

Paper received : 09.06.2017

Revised received : 25.10 .2017

Re-revised received : 30.11 .2017

Accepted : 28.12.2017

\begin{abstract}
Aim : To potentially improve the productivity of microalgae for mass culture, growth characteristics and light-saturation index $\left(E_{k}\right)$ in the marine microalga Chlorella vulgaris were investigated under high-celldensity conditions grown in batch cultures.
\end{abstract}

Methodology : Potential changes in the growth characteristics and $E_{k}$ in $C$. vulgaris were investigated during 4 weeks of cultivation. The algae was cultivated in a column reactor at $25^{\circ} \mathrm{C}$ under a surface light intensity of $300 \mu \mathrm{E} \mathrm{m}^{-2} \mathrm{~s}^{-1}$ in a 12-hr light and 12-hr dark cycle.

Results : Cell density increased and reached $2.7 \mathrm{~g}-\mathrm{dw} \mathrm{l}^{-1}$ by the end of culture with an areal production rate of $3.3 \mathrm{~g}-\mathrm{dw} \mathrm{m}^{-2} \mathrm{day}^{-1}$. The specific growth rate reached a maximum of $0.41 \mathrm{day}^{-1}$ when the light intensity per

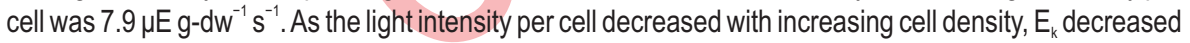
gradually during the first half of the culture period.

Interpretation : Chlorella vulgaris in this study had the ability to acclimate to shade conditions during highcell-density cultivation, however, the photosynthetic efficiency decreased. High transformation efficiency of light energy for photosynthesis in shade-acclimated cells will help to exploit the mass culture of microalgae.

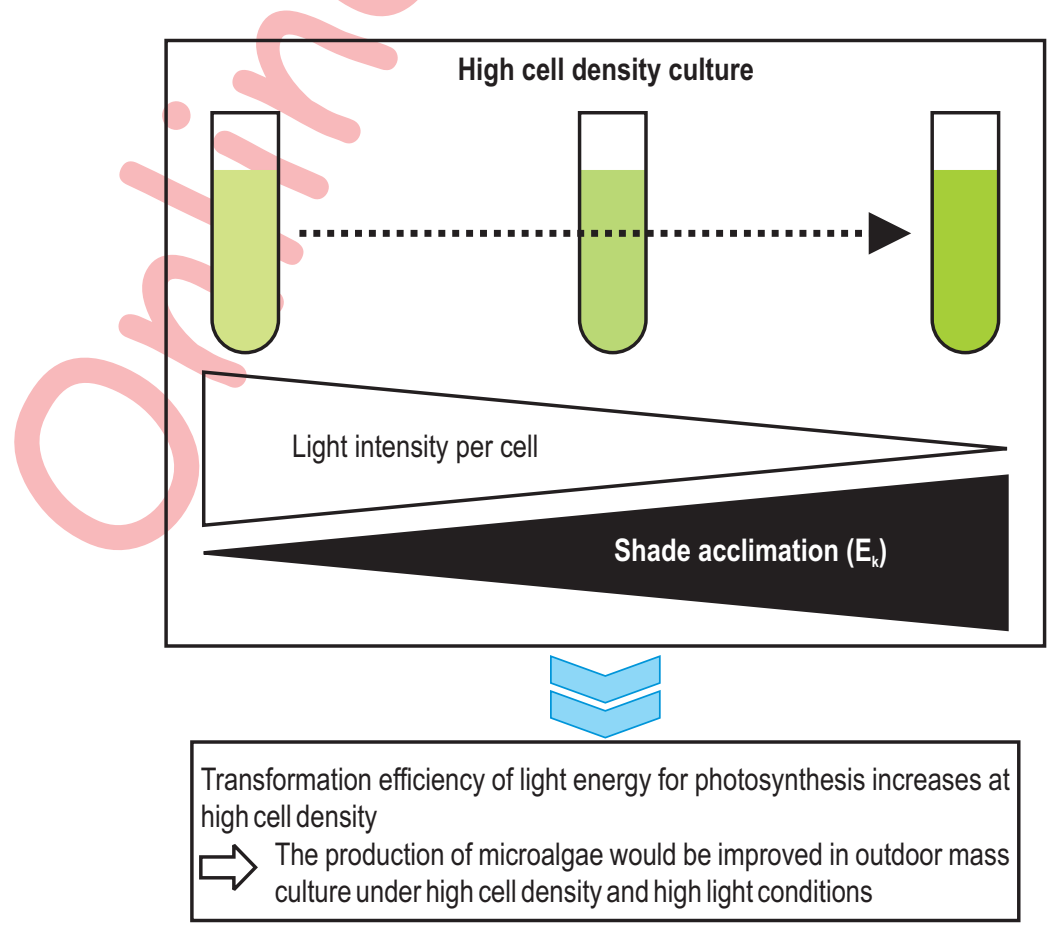




\section{Introduction}

Mass culture of microalgae are receiving increasing attention because of their potential to yield valuable products (Nistan et al., 1999; Zhu and Jiang, 2008), such as sources for biofuels (Gordon and Polle, 2007). Marine algae are particularly well suited for mass culture because they can utilize the vast supply of seawater unlike freshwater algae. The marine green algae Chlorella is recognized as a source of protein and carotenoids for human consumption and animal feeds in aquaculture (Iwamoto, 2004). To exploit these microalgae for large-scale biomass production, it is necessary to obtain a better understanding of the parameters influencing growth and biomass.

Light is a major factor for microalgal growth and must be studied since it provides energy that supports their metabolism. Although algal cells can receive sufficient light energy in low-celldensity conditions, the areal and/or volumetric production rate is lower than those at high densities due to low biomass concentration. On the other hand, denser cell populations enhance production rate. High-cell-density culture has been considered to be one of the effective operational conditions for microalgal production. In high-cell-density cultures, as the algal biomass concentration increases, the penetration of incident light within the algal suspensions gradually decreases due to significant shading effects between the algal cells (Anna et al., 2012; Posten, 2009; Sun et al., 2016) and subsequently, the light intensity per cell decreases (Imaizumi et al., 2016).

Shade-acclimated cells can improve the transformation efficiency of light energy for photosynthesis, and therefore it may be possible to improve the algal biomass production by utilizing these cells. However, it is important to understand the mechanisms of shade acclimation during high cell density culture to effectively produce biomass. The ability of physiological acclimations to low light conditions varies among species (Ziegler and Uthicke, 2011). Shade acclimation of microalgae is commonly reported in accordance with its photosynthetic response to light, particularly in terms of light-saturation index $E_{k}$ (White and Critchley, 1999; Wulff et al., 2008; Katayama et al., 2015). Current knowledge on $E_{k}$ has mainly been obtained through the photosynthetic properties of photosynthesisirradiance curves based on the end products of photosynthesis assessed by the ${ }^{14} \mathrm{C}$ method (Palmisano and Sullivan, 1982). The variable chlorophyll fluorescence method provides information similar to the $E_{k}$ values obtained from the properties of electron transport rate of rapid light curve. This method is largely derived from the chlorophyll associated with photosystem II and is an easy experiment to perform (Maxwell and Johnson, 2000). The $E_{k}$ is considered to be the light intensity that cells use to maintain the balance between photosynthetic energy capture and the capacity of the photosynthetic system to process this energy (Falkowski and Raven, 1997). Shade-acclimation behavior in high-cell- density cultures has not been previously demonstrated in the marine green algae Chlorella. In this study, potential changes in the growth characteristics and $E_{k}$ in marine Chlorella vulgaris were investigated during 4 weeks of cultivation.

\section{Materials and Methods}

Culture condition and experimental design : Chlorella vulgaris was isolated from Port Dickson, Malaysia, and was cultured in a modified Walne's medium (Walne, 1970), which consisted of 0.61 $\mathrm{g}$ of $\mathrm{NaNO}_{3} ; 0.10 \mathrm{~g}$ of $\mathrm{NaH}_{2} \mathrm{PO}_{4} \cdot 2 \mathrm{H}_{2} \mathrm{O} ; 0.23 \mathrm{~g}$ of $\mathrm{Na}_{2}$ EDTA; $0.17 \mathrm{~g}$ of $\mathrm{H}_{3} \mathrm{BO}_{3} ; 6.5 \mathrm{mg}$ of $\mathrm{FeCl}_{3} \cdot 6 \mathrm{H}_{2} \mathrm{O} ; 1.8 \mathrm{mg}$ of $\mathrm{MnCl}_{2} \cdot 4 \mathrm{H}_{2} \mathrm{O} ; 0.21 \mathrm{mg}$ of $\mathrm{ZnCl}, 0.2 \mathrm{mg}$ of $\mathrm{CoCl}_{2} \cdot 6 \mathrm{H}_{2} \mathrm{O}, 0.09 \mathrm{mg}$ of $\left(\mathrm{NH}_{4}\right)_{6} \mathrm{Mo}_{7} \mathrm{O}_{24} \cdot 4 \mathrm{H}_{2} \mathrm{O}$, $0.2 \mathrm{mg}$ of $\mathrm{CuSO}_{4} \cdot 5 \mathrm{H}_{2} \mathrm{O}, 0.1 \mathrm{mg}$ of thiamine $\cdot \mathrm{HCl}, 0.1 \mathrm{mg}$ of cyanocobalamin and $0.002 \mathrm{mg}$ of biotin per liter. The pre-culture was grown in a column reactor at $25^{\circ} \mathrm{C}$ under a surface light intensity of $300 \mu \mathrm{E} \mathrm{m}^{-2} \mathrm{~s}^{-1}$ that utilized cool white fluorescent tubes in a 12-hr light and 12-hr dark cycle. The column reactor was made of glass with an inner diameter of $6.0 \mathrm{~cm}$ and a length of 53 $\mathrm{cm}$ (Fig. 1). The effective volume and the light-receiving area in this reactor were $1.4 \mathrm{I}$ and $2.1 \mathrm{~m}^{2}$, respectively. An airlift system was installed for water circulation, and the culture was aerated with sterile air supplemented with $0.1-0.2 \% \mathrm{CO}_{2}$, at a rate of $0.2 \mathrm{I}$ $\mathrm{min}^{-1}$. The $\mathrm{pH}$ ranged from 8.0 to 6.3 with a $\mathrm{pH}$ buffer solution, and the water temperature was maintained at $25^{\circ} \mathrm{C}$ by circulating thermal-stable water. Triplicate subsamples were collected at 1 , $3,4,7,11,15,19,23$ and 27 days to measure cell density and variable Chl fluorescence.

Analytical methods : To determine the dry cell weight, a cell suspension sample was filtered through a combusted glass fiber filter with a pore size of $0.7 \mu \mathrm{m}$ (GF/F, Whatman, USA). The cell pellet was washed twice with distilled water, dried at $60^{\circ} \mathrm{C}$ for $12 \mathrm{hr}$

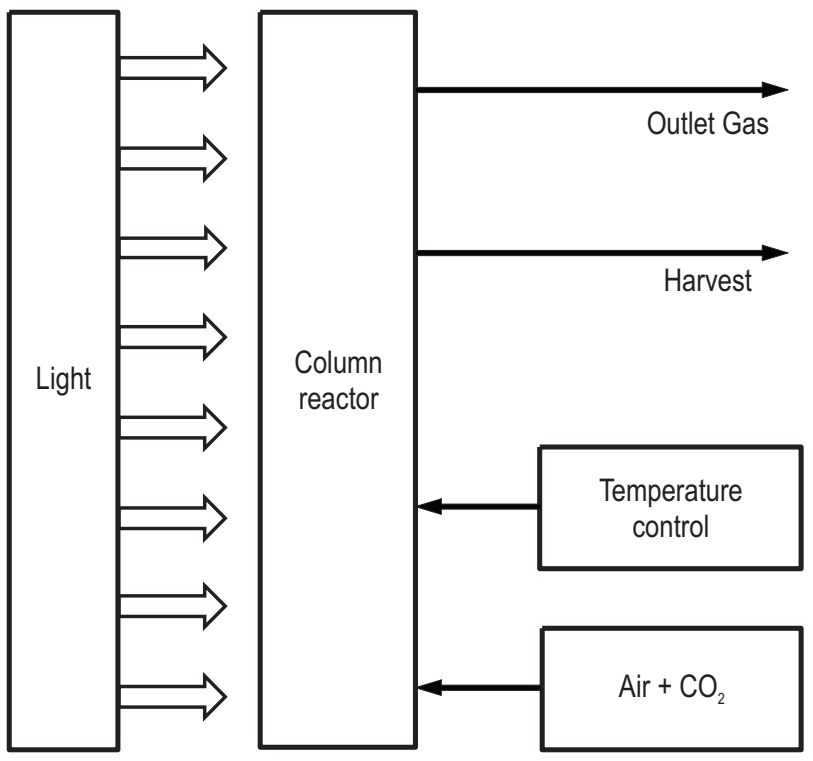

Fig. 1 : Schematic diagram of cultivation system 
and subsequently cooled to room temperature in a desiccator before weighing.

The incident light intensity was measured in the range of photosynthetic active radiation (400-700 $\mathrm{nm}$ ) on the surface of the column reactor using a quantum sensor (QSPL-2100, Biospherical Instruments, USA). The values were in $\mu \mathrm{E} \mathrm{m}^{-2} \mathrm{sec}^{-1}$ that can be converted to light energy $\left(\mathrm{W} \mathrm{m}^{-2}\right)$ by a factor of $0.218(1$ $\left.\mu \mathrm{E} \mathrm{m}^{-2} \sec ^{-1}=0.218 \mathrm{~W} \mathrm{~m}^{-2}\right)$ with cool white fluorescent tubes (Thimijan and Heins, 1983).

The light intensity per unit cell biomass $\left(q: \mu \mathrm{Eg}-\mathrm{dwt}^{-1} \sec ^{-1}\right)$ was calculated as shown below (Yoon et al., 2008; Yoon et al., 2012):

$$
q=\left(21_{0} \times L \times r\right) /(X \times V)
$$

where, $I_{0}$ is the incident light intensity on the surface of the column reactor $\left(\mu \mathrm{E} \mathrm{m}^{-2} \sec ^{-1}\right) ; 1$, rand $V$ are the length $(\mathrm{m})$ and the radius of the reactor tube $(\mathrm{m})$ and the culture volume $(\mathrm{I})$, respectively; and $X$ is the cell density $\left(g-d w l^{-1}\right)$.

Calculation of parameters : As indices of biomass productivity, the specific growth rate $\left(\mu\right.$ : day $\left.{ }^{-1}\right)$, the volumetric production rate $\left(P_{\mathrm{v}}: \mathrm{g}-\mathrm{dw} \mathrm{I}^{-1}\right.$ day $\left.^{-1}\right)$, the areal production rate $\left(P_{\mathrm{A}}: \mathrm{g}-\mathrm{dw} \mathrm{m}^{-2}\right.$ day $\left.^{-1}\right)$, and the photosynthetic efficiency (PE: \%) were calculated according to the following equations:

$$
\begin{aligned}
& \mu=\left(\ln X_{2}-\ln X_{1}\right) /\left(t_{2}-t_{1}\right) \\
& P_{\mathrm{V}}=\left(X_{2}-X_{1}\right) /\left(t_{2}-t_{1}\right) \\
& P_{\mathrm{A}}=\left(V \times\left(X_{2}-X_{1}\right)\right) /\left(A \times\left(t_{2}-t_{1}\right)\right) \\
& P E=\left(P_{\mathrm{A}} \times H_{\mathrm{b}} \times 10^{3}\right) / E_{\text {in }} \times 100
\end{aligned}
$$

where, $X_{1}$ and $X_{2}$ are the cell densities $\left(\mathrm{g}-\mathrm{dw} \mathrm{I}^{-1}\right)$ at time $t_{1}$ and $t_{2}$, respectively. $A$ is the light receiving area $\left(\mathrm{m}^{2}\right) \cdot H_{b}$ and $E_{\text {in }}$ are the enthalpy of dry biomass for $C$. vulgaris (17.44 kJ g-dw: Bhola et al., 2011) and the light energy input $\left(\mathrm{W} \mathrm{m}^{-2}\right)$, respectively.

$\mathrm{Chl}$ fluorescence : Variable $\mathrm{Chl}$ fluorescence was measured with a pulse-amplitude modulated Chl fluorometer (Water-PAM, Walz, Germany). Subsamples for fluorescence analysis were placed in a 15 -mm-diameter quartz cuvette that was illuminated by a circular array of 14 red light-emitting diodes with a peak illumination at $655 \mathrm{~nm}$. To measure photosynthetic capacity, maximum quantum yield of $\mathrm{PSII}\left(F_{\mathrm{v}} / F_{\mathrm{m}}\right)$ was calculated using the following equation (Schreiber etal., 1986):

$$
F_{v} / F_{\mathrm{m}}=\left(F_{m}-F_{0}\right) / F_{m}
$$

where, $F_{\mathrm{m}}$ and $F_{0}$ are the maximum and minimum PSII fluorescence levels of dark-acclimated cells for $30 \mathrm{~min}$ at a given time. A saturation pulse of $3,500 \mu \mathrm{mol}$ photons $\mathrm{m}^{-2} \mathrm{sec}^{-1}$ was applied for 0.8 sec to determine $F_{\mathrm{m}}$. Changes in $F / F_{m}$ are thought to reflect the photosynthetic health of microalgal cells (Cullen and Davis, 2003).
The electron transport rate (ETR) by PSII versus actinic irradiance curves were performed by applying actinic irradiances from 0 to $786 \mu \mathrm{mol} \mathrm{m}^{-2} \mathrm{sec}^{-1}$ using $30 \mathrm{~s}$ illumination periods at each irradiance (Perkins et al., 2006). The ETR was obtained using the following equation (Schreiber etal., 1994):

$$
E T R=P P F D \times \triangle F / F_{\mathrm{m}}
$$

where, PPFD is the photosynthetic photon flux density of actinic light and $\triangle F / F_{\mathrm{m}}$ is the PSIl operating efficiency for illuminated cells (measured at the end of the $30 \mathrm{~s}$ lasting actinic light), which was calculated using the equation of Genty et al. (1989). Parameters based on the ETR observation such as the maximum $\operatorname{ETR}\left(E T R_{\text {max }}\right)$ and the initial slope of the curve $(\alpha)$ were estimated (Webb et al., 1974). To examine the shade-acclimation of cells, the light-saturation index $\left(E_{k}\right)$ was calculated using the following equation:

$$
E_{k}=E T R_{\max } / \alpha
$$

$E_{k}$ that is proportional to the degree of shade-acclimation decreases when cells acclimate to lower light conditions.

\section{Results and Discussion}

Growth characteristics : The cell density increased and stayed at a constant level of $2.0 \pm 0.19 \mathrm{~g}-\mathrm{dw} \mathrm{l} \mathrm{I}^{-1}$ from day 11 to day 19 and then increased again and reached a maximum value of $2.7 \mathrm{~g}-\mathrm{dw} \mathrm{I}^{-1}$ on day 27 (Fig. 2a). The maximum specific growth rate of 0.41 day $^{-1}$ was observed on day 3 , and then the specific growth rate decreased by day 19 as the cell density increased (Fig. 2b). The increase in the specific growth rate resumed after day 19 , and the specific growth rate reached 0.03 day $^{-1}$ on day 27 . The changes in the specific growth rate were observed in a manner similar to the areal production rate, the volumetric production rate and the photosynthetic efficiency (Fig. 2c). The areal production rate is a reliable indicator of algal biomass production, which reached a maximum of $11 \mathrm{~g}-\mathrm{dw} \mathrm{m}^{-2}$ day ${ }^{-1}$ on day 3 even under a light exposure of $300 \mu \mathrm{E} \mathrm{m}^{-2} \mathrm{sec}^{-1}$ that is not high light intensity in outdoor culture conditions. After day 3 , the areal production rate decreased and reached the lowest level of $1.5 \mathrm{~g}-\mathrm{dw} \mathrm{m}^{-2} \mathrm{day}^{-1}$ on day 19 , and then increased and stayed at approximately $3 \mathrm{~g}-\mathrm{dw}$ $\mathrm{m}^{-2}$ day ${ }^{-1}$ after 19 days.

Outdoor mass cultures of microalgae in tropical areas are grown under sunlight exposure in the range of 0 to $2000 \mu \mathrm{E} \mathrm{m}^{-2}$ $\sec ^{-1}$ (Iwamoto, 2004). The daily mean light intensity was approximately $1300 \mu \mathrm{E} \mathrm{m}^{-2} \mathrm{sec}^{-1}$, which is 4.3 times greater than the light intensity of $300 \mu \mathrm{E} \mathrm{m}^{-2} \mathrm{sec}^{-1}$ utilized in this study. Microalgal biomass is produced through the transformation process of light energy, and productivity increases as light intensity increases. This study showed an areal production rate of $3.3 \mathrm{~g}-\mathrm{dw} \mathrm{m} \mathrm{m}^{-2} \mathrm{day}^{-1}$ with a high cell density of more than $2 \mathrm{~g}-\mathrm{dw} \mathrm{I}^{-1}$. It may be possible to improve the areal production rate under a high light irradiance of more than $1000 \mu \mathrm{E} \mathrm{m} \mathrm{sec}^{-1}$ during outdoor cultivation, even though photo-inhibition may occur. 

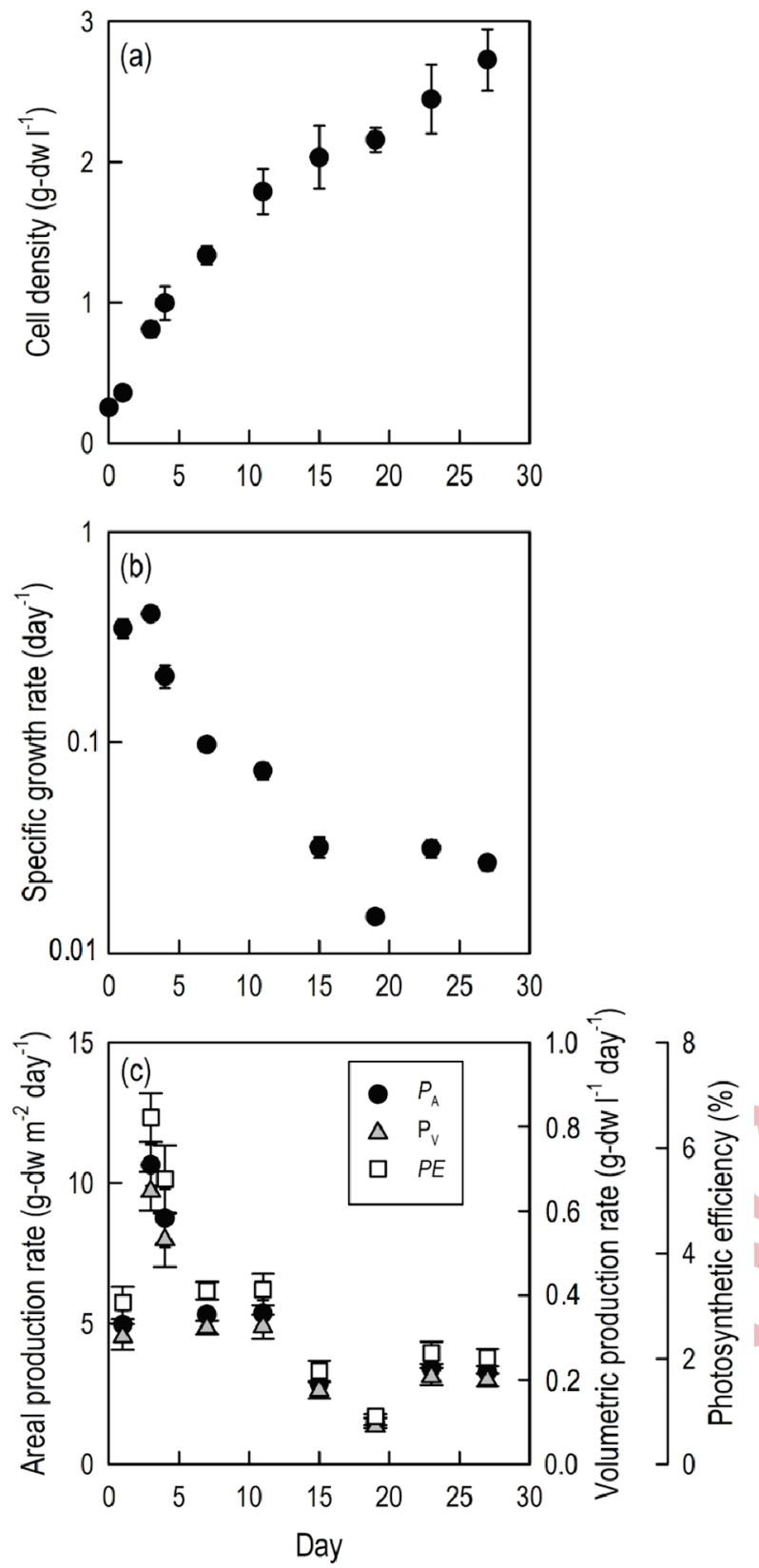

Fig. 2 : Time course of growth characteristics for Chlorella vulgaris. (a) Cell density, (b) specific growth rate, and $(\mathrm{c})$ areal production rate $\left(P_{\mathrm{A}}\right)$, volumetric production rate $\left(P_{\mathrm{B}}\right)$ and photosynthetic efficiency $(P E)$. Error bars indicate one standard deviation

Characteristics of $\mathrm{Chl}$ fluorescence : The maximum quantum yield of PSII $\left(F_{v} / F_{m}\right)$ was 0.65 on day 1 and then became stable between 0.46 and 0.55 after day 3 (Fig. 3). Healthy cells have $F_{v} / F_{m}$ values between 0.6 and 0.8 (Ting and Owens, 1992; Geel et al., 1997; Casper-Lindley and Björkman, 1998; Lippemeier et al., 2001). Additionally, the $F_{v} / F_{m}$ value is relatively constant in nonstressed cultures (White et al., 2011). We hypothesize that the

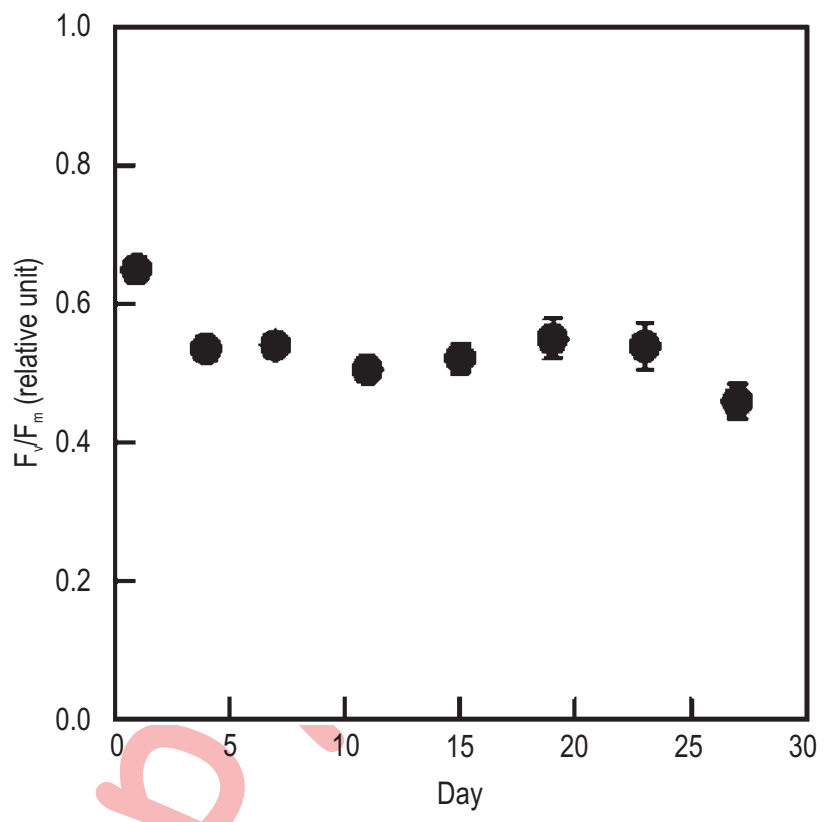

Fig. 3 : Time course of maximum quantum yield of PSII $\left(F_{v} / F_{m}\right)$ for Chlorella vulgaris. Error bars indicate one standard deviation

photosynthetic performance of $C$. vulgaris could be maintained in a healthy state during high-cell-density cultivation, even though its $F_{\sqrt{ }} F_{\mathrm{m}}$ values were lower than 0.6 .

To evaluate shade-acclimation in the cells, the lightsaturation index $\left(E_{k}\right)$ based on the electron transport rate (ETR) is shown in Fig. 4. The $E_{k}$ on day 1 of $290 \mu \mathrm{E} \mathrm{m}^{-2} \mathrm{sec}^{-1}$ coincided with the incident light intensity on the surface of the column reactor (Fig. 4a), indicating that the cells acclimate to ambient irradiance levels. The ETR versus irradiance curve was lower on day 27 than those on day 1 (Fig. 4a). The light-limited slope ( $\alpha$ ) and the lightsaturated rate $\left(E T R_{\max }\right)$ obtained from the ETR versus the irradiance curve decreased gradually with culture time. Consequently, the $E_{\mathrm{k}}$ values decreased from day 1 to day 15 with culture time and then were relatively constant with an average of $171 \pm 22 \mu \mathrm{E} \mathrm{m}^{-2}$ sec $^{-1}$ after day 15 (Fig. $4 \mathrm{~b}$ ). The decrease in the $E_{k}$ suggests the cells became acclimated to shade. Shade acclimation during the first half period of culture might be due to a decrease in the irradiated light intensity for a single cell as the cell density increases. In the second half of the culture period, the $E_{k}$ remained at approximately $170 \mu \mathrm{E} \mathrm{m}^{-2} \mathrm{sec}^{-1}$, although the light intensity per cell decreased continuously until the end of the experiment. The slower rate of change in the $E_{k}$ during the second half of the culture suggests the $C$. vulgaris cells in this study acclimated to a light intensity of approximately $170 \mu \mathrm{E} \mathrm{m}^{-2} \mathrm{sec}^{-1}$.

Relationship between light intensity per cell and growth characteristics : Fig. 5a shows the time course of the light intensity per cell used to evaluate the irradiated light intensity for a single cell at high cell densities. The light intensity per cell 

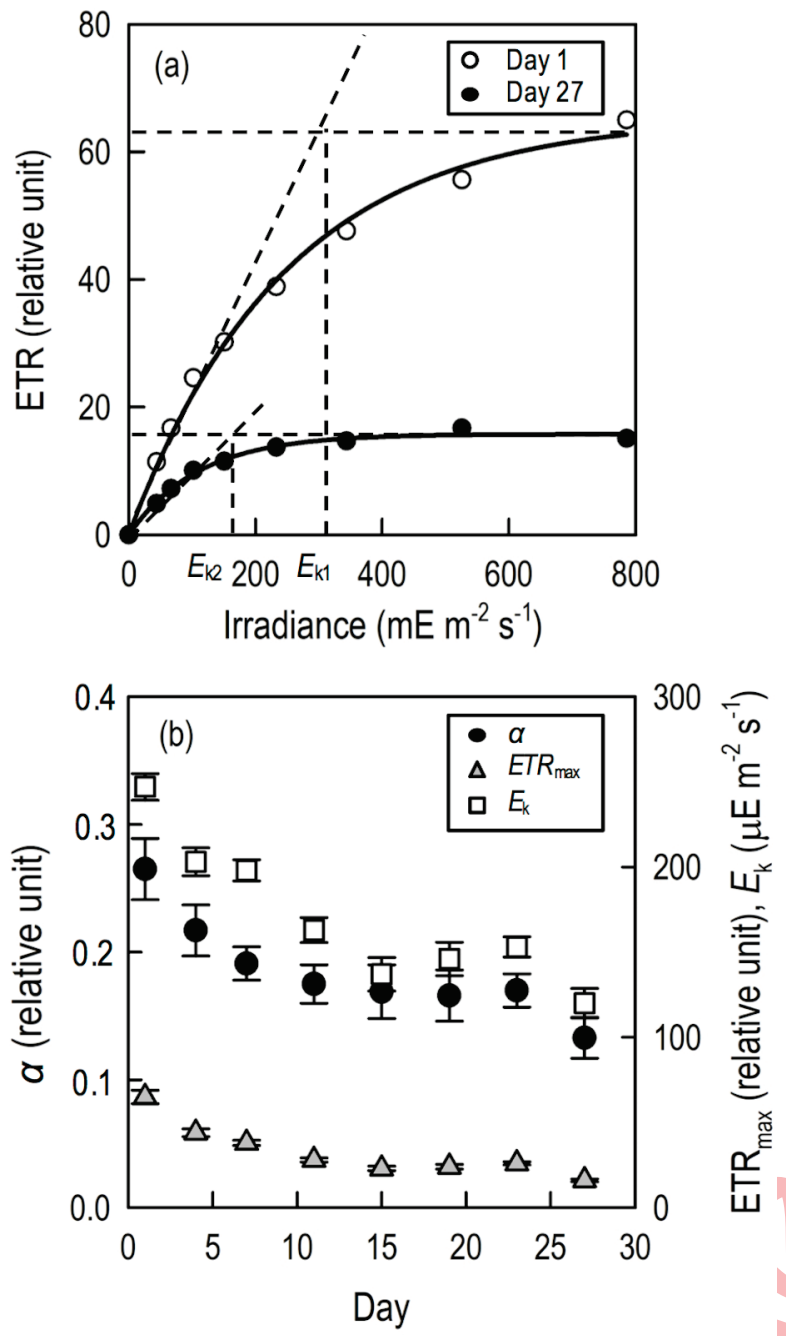

Fig. 4 : (a) Electron transport rate (ETR) versus irradiance curve on day 1 and day 27 and (b) time course of light-limited slope (a), light-saturated rate $\left(\mathrm{ETR}_{\mathrm{max}}\right)$, and light-saturation index $\left(E_{\mathrm{k}}\right)$ for Chlorella vulgaris. $E_{\mathrm{k} 1}$ and $E_{k 2}$ indicate $E_{k}$ on day 1 and day 27 , respectively. Error bars indicates one standard deviation

decreased exponentially with culture time and fell below $10 \mu \mathrm{E} \mathrm{g-}$ $\mathrm{dw}^{-1} \sec ^{-1}$ after day 3 (Fig. 5a). Imaizumi et al. (2014) reported that Chlorella zofingiensis had a high specific growth rate $\left(0.5\right.$ day $\left.^{-1}\right)$ when the light intensity per cell was greater than $28 \mu \mathrm{E} \mathrm{g-dw^{-1 }}$ $\mathrm{sec}^{-1}$. In this study, the maximum value of the specific growth rate was observed when the light intensity per cell was $7.9 \mu \mathrm{E} \mathrm{g-dw}$ $\sec ^{-1}$, suggesting the growth rate in $C$. vulgaris could reach relatively high levels even under low light conditions. The increase in the specific growth rate by increasing the light intensity per cell in this study (Fig. 5b) has also been observed in freshwater C. zofingiensis (Imaizumi et al., 2014). Chlorella vulgaris and $C$. zofingiensis are marine and freshwater algae, respectively, but both have similar specific growth rates under low light intensity per cell. Because C. zofingiensis displayed higher values of specific growth under higher light intensity per cell
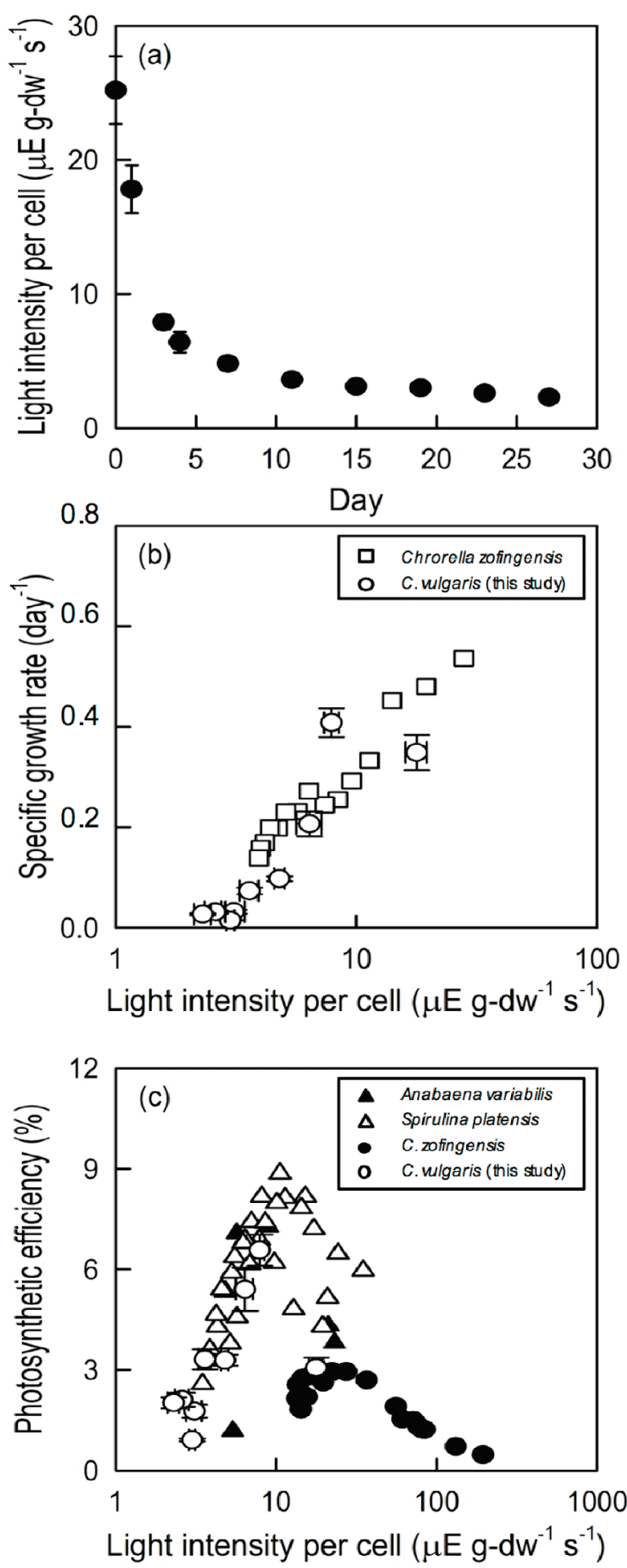

Fig. 5 : (a) Time course of light intensity per cell for Chlorella vulgaris; (b) the relationship between light intensity per cell and specific growth rate and (c) the relationship between light intensity per cell and photosynthetic efficiency in this study (open circle) and in the literature (open square, Imaizumi et al., 2014; open triangle, Yoon et al., 2012; solid triangle, Hu et al., 1998; solid circle, Imaizumi et al., 2016). Error bars indicate one standard deviation 
(Imaizumi et al., 2014), the higher specific growth rate of $C$. vulgaris may be observed when the cells are exposed to higher light intensity. Further studies regarding the light intensity per cell under sufficient light intensity will help to identify the effective operational conditions for outdoor mass culture to increase biomass productivity.

Species-specific growth characteristics with light intensity for $C$. vulgaris, the relationship between the light intensity per cell and the photosynthetic efficiency is shown in Fig. $5 \mathrm{c}$. The photosynthetic efficiency increased with decreasing light intensity per cell. However, under low light intensity per cell at high cell density, it is likely that the photosynthetic efficiency decreased in this study of $C$. vulgaris and as previously demonstrated in $C$. zofingiensis (Imaizumi et al., 2016), Spirulina platensis (Hu et al., 1998) and Anabaena variabilis (Yoon et al., 2012). Other studies suggested that this decrease could be due to the increased viscosity of the culture with increasing cell density, consequently causing the cells at high density to utilize light energy and nutrients less effectively (Lee and Low, 1991) as well as photorespiration rates increasing due to high cell densities (Ugwu et al., 2008). Interestingly, these microalgae displayed similar values of the photosynthetic efficiency under low light intensity per cell with the exception of $C$. zofingiensis that displayed a lower photosynthetic efficiency (Imaizumi et al., 2016). Imaizumi et al. (2016) cultured C. zofingiensis in a tubular photobioreactor with extreme high cell density conditions of $>10 \mathrm{~g}$-d.w. $\mathrm{I}^{-1}$ and high light exposure $\left(>1500 \mu \mathrm{E} \mathrm{m} \mathrm{m}^{-2} \mathrm{sec}^{-1}\right)$. The lower values of photosynthetic efficiency observed in C. zofingiensis (Imaizumi et al., 2016) might be caused by nutrient deficiencies or increased photorespiration.

This study demonstrated that, while the cells of marine green algae $C$. vulgaris acclimate to the low light condition in highcell-density cultures, the photosynthetic efficiency decreases. This inhibition of algal growth at high cell density correlates with the results from previous studies. To increase the transformation efficiency of light energy for photosynthesis in the shadeacclimated cells at high cell density would be important to further research in order to facilitate effective outdoor mass culture of microalgae.

\section{Acknowledgments}

This research was supported by the Japan Science and Technology Agency (JST)/Japan International Cooperation Agency (JICA) through their Science and Technology Research Partnership for Sustainable Development (SATREPS) program and matching funds from the Ministry of Higher Education (MOHE) Malaysia in 2016.

\section{References}

Anna, J., E.C. Bucharsky, S.K. Guenter, P. Habisreuther, R. Oberacker, M.J. Hoffmann, N. Zarzalis and C. Posten: The application of transparent glass sponges for improvement of light distribution in photobioreactors. J. Bioprocess Biotech., 2, 2-8 (2012).

Bhola, V., R. Desikan, S.K. Santosh, K. Subburamu, E. Sanniyasi and F. Bux: Effects of parameters affecting biomass yield and thermal behaviour of Chlorella vulgaris. J. Biosci. Bioeng., 111, 377-382 (2011).

Casper-Lindley, C. and O. Bjöerkman: Fluorescence quenching in four unicellular algae with different light-harvesting and xanthophyllscycle pigments. Photosynth. Res., 56, 277-289 (1998).

Cullen, J.J. and R.F. Davis: The blank can make a big difference in oceanographic measurements. Limnol. Oceanogr. Bull., 12, 29-35 (2003).

Falkowski, P. and J.A. Raven: Aquatic photosynthesis. Blackwell Science, Oxford (1997).

Geel, C., W. Versluis and J.F.H. Snel: Estimation of oxygen evolution by marine phytoplankton from measurement of the efficiency of photosystem Il electron flow. Photosynth. Res., 51, 61-70 (1997).

Genty, B., J. Briantais and N.R. Baker: The relationship between the quantum yield of photosynthetic electron transport and quenching of chlorophyll fluorescence. Biochim. Biophys. Acta., 990, 87-92 (1989).

Gordon, J.M. and J.E.W. Polle: Ultrahigh bioproductivity from algae. Appl. Microbiol. Biotechnol., 76, 969-975 (2007).

$\mathrm{Hu}, \mathrm{Q}$., Y. Zarmi and A. Richmond: Combined effects of light intensity, light-path and culture density on output rate of Spirulina platensis (Cyanobacteria). Eur. J. Phycol., 33, 165-171 (1998).

Imaizumi, Y., N. Nagao, F.M. Yusoff, N. Kurosawa, N. Kawasaki and T. Toda: Lumostatic operation controlled by the optimum light intensity per dry weight for the effective production of Chlorella zofingiensis in the high cell density continuous culture. Algal Res., 20, 110-117 (2016).

Imaizumi, Y., N. Nagao, F.M. Yusoff, S. Taguchi and T. Toda: Estimation of optimum specific light intensity per cell on a high-cell-density continuous culture of Chlorella zofingiensis not limited by nutrients or $\mathrm{CO}_{2}$. Bioresour. Technol., 162, 53-59 (2014).

Iwamoto, $\mathrm{H}$.: Industrial production of microalgal cell-mass and secondary products - major industrial species Chlorella. In: Handbook of Microalgal Culture: Biotechnology and Applied Phycology (Ed.: A. Richmond). Brackwell Science, Oxford, pp. 255-263 (2004).

Katayama, T., A. Murata and S. Taguchi: Photosynthetic activation of the dark-acclimated diatom Thalassiosira weissflogii upon light exposure. Plankton Benthos. Res., 10, 98-110 (2015).

Lee, Y.K. and C.S. Low: Effect of photobioreactor inclination on the biomass productivity of an outdoor algal culture. Biotechnol. Bioeng., 38, 995-1000 (1991).

Lippemeier, S., R. Hintze, K.H. Vanselow, P. Hartig and F. Colijn: In-line recording of PAM fluorescence of phytoplankton cultures as a new tool for studying effects of fluctuating nutrient supply on photosynthesis. Eur. J. Phycol., 36, 89-100 (2001).

Maxwell, K. and G.N. Johnson: Chlorophyll fluorescence- A practical guide. J. Exp. Botany, 51, 659-668 (2000).

Nitsan, Z., S. Mokady and A. Sukenik: Enrichment of poultry products with $\Omega 3$ fatty acids by dietary supplementation with the alga Nannochloropsis and mantur oil. J. Agri. Food Chem., 47, 5127-5132 (1999).

Palmisano, A.C. and C.W. Sullivan: Physiology of sea ice diatoms. I. Response of three polar diatoms to a simulated summer-winter transition. J. Phycol., 18, 489-498 (1982).

Perkins, R.G., J.L. Mouget, S. Lefebvre and J. Lavaud: Light response 
curve methodology and possible implications in the application of chlorophyll fluorescence to benthic diatoms. Mar. Biol., 149, 703-712 (2006).

Posten, C.: Design principles of photo-bioreactors for cultivation of microalgae. Eng. Sci., 63, 165-177 (2009).

Schreiber, U., W. Bilger and C. Neubauer: Chlorophyll fluorescence as a nonintrusive indicator for rapid assessment of in vivo photosynthesis. In: Ecophysiology of photosynthesis (Eds.: E.D. Schulze and M.M. Caldwell). Springer, Berlin, pp. 49-70 (1994).

Schreiber, U., U. Schliwa and W. Bilger: Continuous recording of photochemical and non-photochemical chlorophyll fluorescence quenching with a new type of modulation fluorometer. Photosynth. Res., 10, 51-62 (1986).

Sun, Y., Y. Huang, Q. Liao, Q. Fu and X. Zhu: Enhancement of microalgae production by embedding hollow light guides to a flat-plate photobioreactor. Bioresour. Technol., 207,31-38 (2016).

Thimijan, R.W. and R.D. Heins: Photometric, radiometric and quantum light units of measure: A review of procedures for interconversion. Hort. Sci., 18, 818-822 (1983).

Ting, C.S. and T.G. Owens: Limitations of the pulse-modulated technique for measuring the fluorescence characteristics of algae. Plant Physiol., 100, 367-373(1992).

Ugwu, C.U., H. Aoyagi and H. Uchiyama: Photobioreactors for mass cultivation of algae. Bioresour. Technol., 99, 4021-4028 (2008).

Walne, P.R.: Studies on the food value of nineteen genera of algae to juvenile bivalves of the genera Ostrea, Crassostrea, Mercenaria and Mytilus. Fish. Invest. London Ser., 2, 24, 1-62 (1970).

Webb W.L., M. Newton and D. Starr: Carbon dioxide exchange of Alnus rubra: A mathematical model. Oecologia, 17, 281-291 (1974).

White, S., A. Anandraj and F. Bux: PAM fluorometry as a tool to assess microalgal nutrient stress and monitor cellular neutral lipids. Bioresour. Technol., 102, 1675-1682 (2011).

White, A.J. and C. Critchley: Rapid light curves: A new fluorescence method to assess the state of the photosynthetic apparatus. Photosynth. Res., 59,63-72 (1999).

Wulff, A., M. Roleda, K. Zacher and C. Wiencke: Exposure to sudden light burst after prolonged darkness -A case study on benthic diatoms in Antarctica. Diatom Res., 23, 519-532 (2008).

Yoon, J.H., J.H. Shin, E.K. Ahn and T.H. Park: High cell density culture of Anabaena variabiliswith controlled light intensity and nutrient supply. J. Micrbiol. Biotechnol., 18, 918-925 (2008).

Yoon, J.H., S.S. Choi and T.H. Park: The cultivation of Anabaena variabilis in a bubble column operating under bubbly and slug flows. Bioresour. Technol., 110, 430-436 (2012).

Zhu, Y.H. and J.G. Jiang: Continuous cultivation of Dunaliella salina in photobioreactor for the production of $\beta$-carotene. Eur. Food Res. Tech., 227, 953-959 (2008).

Ziegler, M. and S. Uthicke: Photosynthetic plasticity of endosymbionts in larger benthic coral reef Foraminifera. J. Exp. Mar. Biol. Ecol., 407, 70-80 (2011).

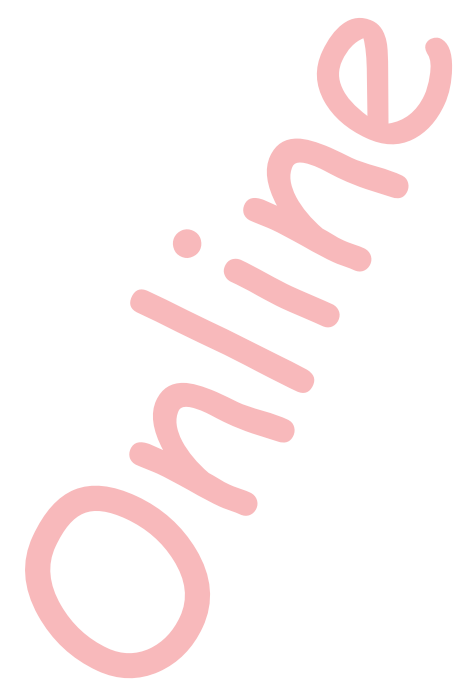

